CSP article 1540 post resub edit

https://doi.org/10.1177/0261018317745609

\title{
The role of discourse in family policy reform - the case of Finland
}

Josefine Nyby, Mikael Nygard, Janne Autto, Mikko Kuisma. Sonja Blum

\begin{abstract}
Since 2011 and the onset of the economic crisis, Finnish governments have pressed for structural reforms, including unpopular cuts to family benefits and services. This article analyses the government discourse used for legitimating some of these reforms: the cutbacks in the child benefit and the restriction of full-time childcare. It also assess whether this discourse bore the hallmarks of a neoliberal austerity discourse, which could suggest that the reforms were not just a matter of fiscal balancing but also a matter of neoliberal welfare state restructuring. We argue that the economic crisis was central in the powerful 'communicative' discourse used by the governments for legitimating unpopular cuts. Not only did it draw on ideas from an austerity discourse advocating financial sustainability, fiscal prudency and debt reduction, it was also impregnated by ideas from a neoliberal worldview questioning some of the main principles of the 'Nordic' family policy model.
\end{abstract}

Keywords: family policy, reform, discourse, economic crisis, Finland, austerity, neoliberalism, Nordic model of welfare

\section{Introduction: background, objectives and methods}

In the comparative welfare state literature, Finland has been considered a member of the Nordic family policy model (Bradshaw and Hatland, 2006; Korpi, 2000) characterised by relatively high female employment, family-friendly policies and gender equality (Forssén et al., 2008). Two of the most popular benefits in the Finnish family policy model are the universal child benefit for every child under 17 years (with a supplement for single parents) and the universal public childcare system, which provides childcare for every child under school age (which starts at seven). These have played a central role for the economic wellbeing of families and served as a corner stone for the Finnish dual-earner model (Forssén et al., 2008).

However, since the international financial crisis, the economic foundations of this system have become increasingly undermined. Since 2010, Finnish governments have pressed for cost containment and structural reforms in order to combat economic decline, soaring public debt and falling employment rates. This has led to cutbacks in family policy, such as the cuts in child benefits (in 2012, 2014, and 
2015) and the restriction of the universal right to public childcare (in 2015) - reforms that were highly unpopular among both the public and family policy experts (e.g. Pohjanpalo, 2015) and thus politically risky enterprises (Vis, 2010). Although these reforms were incremental and did not entail dramatic cuts in benefit levels, they can nevertheless be seen as principally important, since they not only challenged the public opinion, but also eroded the idea of universal support for families and Finland's position in the Nordic family policy model (Ahrendt et al., 2015).

The aim of this article is to analyse the discourse used by recent Finnish governments for legitimating the abovementioned unpopular reforms in family policy. Using the concepts of 'communicative' discourse (Schmidt, 2002), austerity (Blyth, 2013; Clarke and Newman, 2012) and neoliberalism (Taylor, 2007; Harvey, 2005) as starting points, we study the legitimating aspects of this discourse, but also to what extent it used ideas from what we call a neoliberal austerity worldview, which in turn could suggest that the reforms were not just a matter of fiscal balancing but step towards a reconfiguration of Finnish family policy in a neoliberal fashion. The research questions are: a) what policy recommendations, arguments, and ideas were used in this discourse? b) to what extent did this discourse relate to a neoliberal austerity worldview? c) how effective was this discourse in creating political and public consent for cutbacks in these abovementioned welfare programs?

In order to answer these questions, we used a triangulated methodological approach (Rothbauer, 2008) focussed on the analysis of discourse (cf. Schmidt, 2002: 170) that combines various data sources and methods in search of a richer and more nuanced picture of a phenomenon. In our case we use a qualitative content analysis for identifying policy recommendations, arguments and ideas, that is, legitimating aspects of political discourses, rather than discourse analysis in a strict postmodern or deconstructionist sense (Jorgensen and Phillips, 2002). For this end, we combined inductive and deductive qualitative content analysis (e.g. Hsieh and Shannon, 2005) of government and parliamentary documents with expert interviews and analyses of survey data on government support ${ }^{\mathrm{ii}}$. In short, in relation to the first research question, we inductively analysed government programs and bills for policy recommendations, arguments and ideas, and for the second research question, we deductively analysed these arguments and ideas to establish to what extent these relate to a neoliberal worldview (see Tables 1 and 2). In relation to the third research question pertaining to the 'effectiveness of the discourse, that is, the 
level of consent (or opposition) that it created, we performed content analyses of minutiae (protocols) from debates in the Finnish parliament [the Eduskunta] and articles and editorials from the leading daily newspaper in Finland (Helsingin Sanomat).iii Furthermore we conducted five non-structured and qualitative interviews with leading family policy experts. The main idea here is that the efficiency of the governments' austerity discourse is at least partly discernible from the degree of consent/opposition it causes among (competing) politicians and media. ${ }^{\text {iv }}$ The coding of documental content was performed by two of the authors, and the coding process consisted of two stages: first, an initial reading was conducted to get a sense of the whole, whereupon the actual coding of the document commenced for each of the four cutbacks. ${ }^{\vee}$ The coding process was checked for accuracy and inter-reliability on regular occasions. The five expert interviews were conducted in the fall of 2014 with leading researchers and experts in Finnish family policy.

The paper contributes to the literature on discourse of welfare state reform (e.g. Hemerijck, 2013; Schmidt, 2002, 2008) and the power of neoliberal austerity ideas (Harvey, 2005; Farnsworth and Irving, 2015; Clarke and Newman, 2012), by showing how the economic crisis, and ideas from an austerity and neoliberal discourse, became intertwined in a powerful 'communicative' discourse that helped recent Finnish governments to legitimate unpopular cuts in family policy - even at the expense of the 'Nordicness' of the Finnish family policy model. In this respect Finland serves as an interesting case in comparison with, for example, Iceland where the financial crises did not lead to similar cutbacks in the welfare state (Stuckler and Basu, 2013). The rest of the article is structured as follows. Next, the theoretical framework is presented and in the following section we discuss the selected family policy reforms, the discourse underpinning them together with an assessment of their effect. In the final section, a number of conclusions are drawn and discussed.

\section{Ideas, discourses and the power of austerity}

There are many ways of explaining the emergence, design and change of family policy (e.g. Wennemo, 1994). The theoretical starting points for this article can be found in theories about how ideas influence policy (Béland and Cox, 2010; Blyth, 2010) and how they are linked to institutional discourses (Fischer, 2003; Schmidt, 2002, 2008). Put simply, one common assumption here is that ideas and the discourses carrying them matter in politics. Ideas exercise cognitive and normative 
influence on how the social world is constructed and they generate discourses on what needs to be done for changing this world in ways that are conditioned by welfare-institutional configurations. Whereas cognitive ideas refer to logic and observation, telling us what the problem is and what the solutions to them are, normative ideas are attached to values and seek to legitimate policies, that is, telling us why something is important or why something needs to be done (Schmidt, 2008, p. 307).

Schmidt (2008: 306) distinguishes between three categories of ideas: specific policy ideas, general ideas, and 'world views'. While specific policy ideas offer a solution to a certain problem, the more general ideas and 'world views' entail larger ideational constructions on society, economics or politics, and they also offer some kind of normative justification for specific policy ideas. As an example: 'privatization' can be seen as a specific policy idea, which in turn is related to a more general idea on 'market efficiency' in accordance with a neoliberal 'world view' (or ideology), which sees markets as self-regulating and state intervention as ineffective (Taylor, 2007).

Also, the term discourse can be defined in a multitude of ways. On a very general level, a distinction can be made between discourse as communicative interaction and discourse as a struggle for precedence of interpretation (cf. Jorgensen and Phillips, 2002). While the former notion focuses more squarely on how different actors communicate and for example use arguments in order to create legitimacy, the latter uses more subtle analyses of language shape thought, or how different discourses compete with each other (ibid.). Schmidt (2002: 169) follows the former tradition in defining discourse as 'whatever policy actors say to one another and to the public more generally in their efforts to construct and legitimate their policy programs'. In this article, discourse is defined in a similar vein by referring to what governments 'say' about the need to pursue cutbacks in family policy, that is, the argumentation and ideas they invoke in order to legitimate cutbacks. According to Schmidt (2008), this often takes place in communicative discourses. Such discourses are directed towards the public and explain a reform so the public may accept it, whereas coordinative discourses take place within the government and relate to technical aspects of how to carry out a specific reform. According to Schmidt (2002), these two discourses are both present in all policy making, but while the subjects of the discourses might be the same, the objectives and audiences are not. 
A central notion in discursive institutionalism is that discourses are conditioned by institutional configurations and that communicative discourses are more prevalent in welfare states with more centralised power and less coordinated decision-making systems (Schmidt, 2002). This is also largely the case with Finland, where the decision-making process is rather centralised when it comes to tax-funded family benefits, such as the child benefits, and public childcare services, whereas parental leaves are regulated through tripartite negotiations between social partners (LammiTaskula and Takala, 2009). ${ }^{\text {vi }}$ Furthermore, child benefits and childcare services are universal with a strong sense of 'citizen right' (Lammi-Taskula and Salmi, 2013). Taken together, this means that governments are accountable to voters for possible cutbacks in tax-funded family benefits and childcare services, which accentuates the need to 'avoid blame' (Vis, 2010) through, for instance, powerful communicative discourses that obfuscate the responsibility for unpopular cutbacks (Schmidt, 2002). In this article we focus on one particular set of communicative discourse, the socalled austerity discourse, which puts ideas of fiscal parsimony, government debt reduction and cost containment in the front (Blyth, 2013; Clarke and Newman, 2012; Farnsworth and Irving, 2015b). But we are also interested in how such a discourse may be related to neoliberal ideology (Taylor, 2007; Harvey, 2005).

According to Farnsworth and Irving (2015: 1) Europe has entered a 'new age of austerity', which is characterised not only by a stronger focus on fiscal balance and tighter budget control, but also by cuts in public social expenditure and debt at the same time as it praises tax reductions and a de-regulation of labour markets. Although austerity is hard to pinpoint empirically both as a discourse and as a political phenomenon, the austerity discourse that surfaced after the international financial crises can be said to differ from earlier representations through its dominant position of being the 'only alternative' in debates on public policy and the welfare state (Blyth, 2013; Farnsworth and Irving, 2015; O'Hara, 2014; Clarke and Newman, 2012). According to Blyth (2013: 226), it is a 'dangerous idea', since it is not only selfdefeating through its social costs and its incapacity to increase growth, but it is also 'ideologically immune to facts and basic empirical refutation'.

The austerity discourse of today also seems to be highly influenced by neoliberal ideology (Taylor, 2007; Harvey, 2005), since tends to view welfare state expansion, fiscal stimulus and government spending as 'logical' anathemas while at the same time advocating expenditure cuts, tax reductions, less state involvement 
and greater wage and wealth dispersion in a neoliberal fashion (Blyth, 2013; Clarke and Newman, 2012). It has also been used as a default strategy to respond to economic by cutting debt and public expenditures for the general population while simultaneously 'protecting the power and advantages of capitalist elites' (McBride, 2015: 68). This is why Clarke and Newman (2012) rightfully refer to this discourse as 'alchemy'; i.e. as an ideologically driven 'quick-fix' in times of neoliberalism and globalisation. On the basis of this discussion it seems reasonable to view austerity discourses as a discursive offshoot of, or as a 'naturalised common-sense' continuation, of the neoliberalism that 'strangely did not die' (Crouch, 2011). Table 1 thus highlights the key values, norms for public action as well as policy ideas of what we choose to call a neoliberal austerity worldview as compared to a Keynesian and a social investment worldview.

\section{[TABLES 1 AND 2 SOMEWHERE AROUND HERE]}

While Keynesian worldview, focusing on demand-side social policy and far-reaching equality ambitions, can be seen as a blue-print for Finnish welfare state expansion until the 1990s, the social investments worldview with a stronger focus on activation, human capital investments and 'flexicurity' became more pronounced in family policies of the late-1990s and early-2000s (Anttonen and Sipilä, 2012). Although Finland has experienced times of austerity politics before, most notably in the 1990s, with massive cutbacks in income transfers to families, these phenomena have been rather short-lived. However, after the international financial crisis in 2008-09 the focus on austerity politics grew stronger in Finland and became one of the most primarily objectives of the conservative-left coalition led by Prime Minister Katainen (Nygård and Autto, 2014; Ahrendt et al., 2015). One of the main goals for this coalition was to achieve financial sustainability through structural reforms, containment of public expenditure and debt reduction (ibid.), which not only proved hard to achieve but also caused protests and strikes (e.g. Reuters, 2015). This does not mean, however, that Keynesian or social investment ideas have been replaced altogether. Instead, it suggests that the competition between these worldviews and neoliberal ideas have become fiercer and that the recent economic crisis has opened up for ideological renegotiations of the welfare state. As displayed in table 1, some of the key values of this worldview relate to individual responsibility, freedom and 
equality in opportunity, whereas the general ideas relate to a limited state with a preoccupation for fiscal constraint and free and self-regulated markets. According to this view, family policy still plays a role, but not necessarily in a universal or an encompassing sense, since its main precedence concerns poverty reduction (Morel et al., 2012) rather than securing economic wellbeing or equality of families with children. This is the context in which recent governments in Finland, starting with the Katainen government in 2011 , have set out to pursue unpopular reforms.

\section{Findings}

The results show that all three governments (Katainen, Stubb, and Sipilä) employed elements from an austerity discourse in order to pursue unpopular cutbacks in child benefits (2012, 2014 and 2015) and in the subjective right to childcare (2015). This can be seen, for instance, through the strong position that policy ideas proposing cost containment and debt control have had in the governments' discourses and how they trumped over old-style social policy ambitions. Moreover, this discourse has been successful, since the governments have succeeded to achieve unpopular cuts without any dramatic costs in electoral support ${ }^{\text {vii }}$ and despite criticism from both the opposition and policy experts. Below we examine the discourse used by the Katainen, Stubb and Sipilä governments, and how it was received by opposition MPs, amongst family policy experts, and the media.

\section{The cutbacks in the child benefits}

In accordance to the Nordic model of welfare, the main objectives of Finnish family policy have been to redistribute income between families with and without children (Hiilamo 2002). The popular child benefit, which became universal in the late 1940s, has worked as an efficient measure in economically compensating families with children. Regardless of its popularity, in 2012, PM Katainen's Government presented a temporary index freezing of the child benefit for three years with effect from 2013 (Government bill, 116/2012). This measure was mainly motivated by economic arguments, according to which cutting public expenditures, the child benefits included, is a necessity to restore financial sustainability and prevent government debt in times of sluggish growth. This exemplifies a specific policy idea, but also a more normative general idea in line with a neoliberal austerity worldview outlined in Table 1, as it signifies supremacy of fiscal prudence and debt control over principles 
of social welfare and equality, and depicts expenditure cuts as a way of 'saving' the welfare state.

In addition, arguments of diminution and compensation were frequently used in order to legitimate the cutback. Not only was the overall economic importance of the child benefit downplayed, which suggests the impact of the reform on families to be minimal (ibid.: 4), but vulnerable groups, such as single parents, were to be compensated by a raise in the single-parent supplement to child benefits. Legally speaking the cutback was seen as posing no problem since 'according to the constitution, the social security can to some extent be lowered in accordance with the economic resources' of the country (ibid.: 4).

A closer inspection of the ideational logic behind the government austerity discourse suggests a mixture of so-called cognitive and normative ideas (Schmidt, 2008). Whereas cognitive elements can be traced in the attempt to invoke a 'common-sense' notion on the need to stabilise the public economy, the normative elements are represented by the expectation that austerity measures will 'generate economic stability' and 'balance state finances in the long run' (ibid.: 4). In other words, there is a belief that cuts in the short run yield financial stability and growth in the long run, which rhymes with a neoliberal austerity discourse. However, the ambition to safeguard the economic wellbeing of vulnerable families suggests that the government also, to some extent, sought to uphold old-style Keynesian and social investment traditions of social equality.

This is also largely true for the governments of PM Stubb and PM Sipilä. Also in the programmes of these two governments the economic situation and the rising level of public debt served as foundation for and justification of for structural reforms and cutbacks in social policies and services. In 2014, PM Stubb's Government launched a number of reforms aiming at curtailing public expenditures and making the social security system more activating (Government Program, 2014). Among other things, an $8.1 \%$ cutback in the child benefit was proposed (Government bill, 165/2014). The argument behind this cutback was mainly an argument of economic necessity; in times of economic hardships, the state has no other alternative than to renegotiate its social policy commitments and even cut back on child benefits regardless of their importance and popularity.

The idea of adjusting public consumption to shrinking resources served as a powerful framing of unpopular reforms, and it became even more powerful when 
backed up by a context of a 'weak global economy' (especially in the Euro-zone) and 'the restructuring of the Finnish industry' (ibid.: 4). The cutback was also underpinned by arguments of compensation: the single-parent supplement was to be retained and a child tax credit to be introduced for the poorest families (Government bill, 165/2014: 4-6). Normatively speaking, the cutback was informed by ideas of an allegedly positive outcome of cost containment on growth. Accordingly, austerity measures were needed to recover from the recession, even at a price of higher child poverty rates. Although the cutback increases child poverty in the short run, it is still considered the best alternative in the long run, as it improves the financial sustainability of the social security system thus helping to preserve the welfare state. According to Blyth (2013) the narrative of future gains from cost containments is typical for a neoliberal austerity worldview; its strength emanates from the idea that such measures will boost investors' expectations and thus 'produce expansion by cutting' social expenditure (Blyth, 2013: 212). Furthermore, the cutback was considered as just, as it is 'equally big' and affects families in a similar way (ibid.: 4).

In 2015, PM Sipilä continued to pursue cutbacks by proposing a cancellation of the child benefit indexation system with effect from January 2016 (Government bill, 70/2015). Similar to earlier cutbacks, this reform was legitimated mainly through economic arguments; public expenditure must be adjusted in relation to economic resources, even if this means cutbacks (Supplement to Government program 2015: 8). Cognitive ideas referring to economic sustainability, frugality and modesty were used (e.g. 'We [Finns] do not live on borrowed money', ibid.: 5), but there were also referrals to historical experiences of hardship (the winter war, previous crises etc.) and personal sacrifice (solidarity) suggesting that 'Finns understand that in the middle of the crisis, difficult decisions have to be made' (ibid.: 7). Also, normative ideas referring to neoliberal values of 'liberty', 'own responsibility' and 'less [state] regulation' nurtured the argumentation behind the reforms (Supplement to Government program 2015: 5). Accordingly, the balance between the state and the individual needs to be renegotiated by giving individuals more responsibility and cutting state regulation - something that fits in with the neoliberal ideology behind the austerity discourse (cf. Taylor, 2007).

How, then, were the abovementioned cutbacks in child benefits received by other politicians, family policy experts and the media, that is, how 'effective' was the governments' austerity discourse in creating consent in terms of the cutbacks in child 
benefits? Although we cannot in fact measure this 'effect', the analysis suggests that the (neoliberal) austerity discourse was quite powerful. All three cutbacks were discussed with varying intensity in the Eduskunta, especially the 2014 cutback in the child benefit level caused a lengthy and heated debate (PTK 89/2014) resulting in mixed reactions, creating both consent and opposition. Whereas politicians from government parties agreed with the Government on most of the cutbacks, the politicians from opposition parties generally jibbed at the proposals. When it came to the 2012 indexation freezing of the child benefit (HE 116/2012), politicians from the opposition suggested that cutting this benefit 'undermines the importance of the child benefit' and that it will 'decrease the income of families already on a small income' (Hänninen, Left, PTK 89/2014). The opposition also pointed out that a cut will increase child poverty and diminish consumption, which in turn undermines growth.

Also, the 2014 cutback in the child benefit level (HE 165/2014) led to both consent and opposition in the parliament, and that this reform was controversial is traceable from the large number of speakers (altogether 108 as compared to 8 in 2012). Similar to 2012, MPs from government parties largely argued and voted for the cut, while politicians from the opposition parties argued and voted against the proposal. The government MPs emphasised that 'cutting the child benefit feels bad' but that refraining from cuts will lead to 'all the welfare services [being] at stake' (Wallinheimo, KOK, PTK, 89/2014). The opposition MPs suggested that this was 'more than anything an ideological choice' (Niikko, TF, 89/2014), as 'these kinds of inhumane decisions ruin the welfare state' (Mäntylä, TF, PTK, 115/2014) and that 'the IMF have shown that the Euro crisis have been dealt with in the wrong ways by pursuing austerity measures' (Modig, LEFT, PTK 89/204). Furthermore, the opposition MPs argued that such a cutback jeopardizes the well-being among families (Mäkipää, FP, 89/2014) and that families with children have been hit disproportionally hard in the government's cost containment scheme (Juvonen, TF, PTK 155/2014). The opposition MP's also said that there are other and more just ways of containing social expenditure (Rantakangas, CEN, PTK 155/2014) and that the future prospect of the child is undermined by the cutback (Juvonen, TF, PTK 155/2014). A similar division was visible in 2015 when the indexation of the child benefit was abolished (HE 70/2015), but this time the cutback also caused some critique within the government's own ranks, even if the government MPs eventually voted unanimously in favour of the cutback. The number of speeches in the 
Eduskunta was also smaller than in 2014 (49). Some government MPs tried to obfuscate the effect of the reform by arguing that an abolishment of the indexation is not 'a direct cut' (Saarikko, CEN, PTK 53/2015 vp) and that the motive for the reform is purely economic and 'definitely not ideological' (Zyskowicz, KOK, PTK 53/2015). Among opposition MPs, on the other hand, the cutback was largely seen as ideological - as one step in a long-term process of scaling down state responsibility for families (e.g. Pekonen, LEFT, PTK, 53/2015 vp). Furthermore, the opposition suggested that the cutback 'will increase child poverty' (Salonen, SDP, PTK, $53 / 2015$ ), and that the government is not following a predictable (family policy) line (Andersson, LEFT, PTK, 77/2015).

If the parliamentary debate showed both consent and opposition, this was not the case with the family policy experts interviewed for this article. Among the family policy experts, there was an unequivocal opposition to all three reforms, which not only became evident in the interviews, but also in media, as some of the experts used the media to express their opposition to the wider public. All the experts pointed out that austerity measures and increasing unemployment rates have made families suffer economically and some thought that this would have negative long-term effects on family wellbeing. Some of the experts argued that Finland has taken a U-turn towards a scarcer family policy, away from universalism, and that ill-being amongst families will increase despite any compensatory benefits such as the child tax credit (which does not help the poorest families with no income). One expert also suggested that the cutbacks in family policy was not an immediate effect of the economic crisis, but rather an effect of ideological choices made by recent right-wing governments starting with the right-left coalition led by PM Katainen. Furthermore, this expert highlighted that PM Stubb did indeed suggest that everyone, including families with children, has to participate in the cutbacks, suggesting the idea of austerity concerns everyone in society.

In relation to the experts, the reactions to the cutbacks in the child benefits in editorials of the leading Finnish newspaper, Helsingin Sanomat, were more modest although a growing criticism became detectable in 2014. At first, there was no explicit comments on the cutbacks in the child benefits, but in 2014, the tone changed and disappointment over the irresolution of the government and inconsistency in its family policy-making was expressed (HS 29 Mar 2014). The government was criticised for going behind the backs of the people, as the government knew that this cutback 
would affect poor families negatively (HS 7 Apr 2016 and HS 9 Apr 2016).

Furthermore, the introduction of the child tax credit, which was intended to compensate for the cutbacks, was criticised since it was seen to benefit only families with employed parent(s), but not the poorest of families (HS 6 Oct 2014).

\section{The restriction of the subjective right to childcare}

Finland has been known for its universal public childcare system and its subjective right to childcare, which gives parents right to public childcare for all children under seven. The principle of universalism was introduced already in the 1970s, but it became instituted as a 'subjective right' only in the 1990s (Forssén et al., 2008; Hiilamo, 2002), and this right has played an important role in creating social equality among children and in minimizing class division (cf. Välimäki, 1999). In May 2015, the childcare legislation was even updated by strengthening the ideas of early education, early learning, childhood pedagogy and child wellbeing (HE 341/2014). At the same time, however, the economic crisis changed the political climate in Finland and made the government prone to reform and pursue cost containment in family policy. This is a reason why the newly enacted law on early childhood education and care [ECEC] was changed once again in December 2015 (Government bill, 80/2015) leading to a restriction of the right to full-day ECEC for children without both parents in full-time work, education, or on family leave to 20 hours per week. Although this reform did not entail any changes in fees or income testing, it constituted an important break with the previous principle to provide all children under seven, regardless of their parents' labour market status, a right to full-day childcare.

The arguments and ideas used for legitimating this restriction were relatively the same as in the case of child benefits. Not only was this restriction constructed as an economic necessity, but it was also seen as a way of activating parents by using the option of receiving full-day childcare as a 'carrot' for employment. Similar to the cutbacks in child benefits, the restriction of childcare created consent within the government's own ranks, while the opposition MPs and the experts, as well as the media to some extent, opposed the reform. Already in 2011, in the government program of PM Katainen, there was a general creed for austerity measures to the public welfare services, as well as a recommendation of higher flexibility in public childcare. This was motivated by economic arguments, suggesting that an adjustment of the public economy is necessary 'for the future of the welfare services' 
(Government Program, 2011: 7). The idea of sustainability was used as a cognitive idea suggesting that cost containments are both inevitable and natural: 'only a sustainable public economy [...] can guarantee a sustainable welfare' (ibid.: 10). The idea that economic necessity surpasses the principle of social welfare is an example of a normative idea that helped legitimating the cutbacks. Another example is the accentuation of employment: 'the family's income should first and foremost be received through employment', which is also 'the best form of social security' (ibid.: 6). There was, in other words, a building-up of arguments for structural reforms and cost containments already in the 2011 government program, but the actual proposition to restrict public childcare was presented in 2013 (Structural-Policy Program, 2013: 9) with effect from August 2016. Mostly economic arguments and cognitive ideas were employed for legitimating this restriction. Accordingly, structural reforms are necessary in order to close the 'sustainability gap' and for easing the pressure that the demographic change has put on the public sector (ibid.: 1). In addition, the idea that improved productivity and effectiveness of public services lead to higher financial sustainability was central (ibid.: 3). Meanwhile, a normative idea underpinning the restriction was that welfare services ought to be connected to one's employment situation, or 'restricted due to social circumstances' (ibid.: 9), which can be interpreted as a quest for higher selectivity and a stronger accentuation of employment-based social rights on the behalf of universalism.

In 2015, PM Sipilä's government program proposed a restriction of the full-day childcare to 20 hours per week if one parent stays at home due to family leave or unemployment. The main argument was economic; the childcare system costs too much and needs to be downscaled for the state to be able to balance its economy, but also other arguments were used. One built on the idea of compensation, according to which the private (child) care allowance are raised in order to facilitate private care for those children that cannot receive full-day public childcare. Another related to pluralism and targeting, i.e., the restriction still makes it possible for municipalities to provide full-day childcare if they want to, and they are obliged to do so if it seen as necessary due to the child's social or developmental needs (Government Program, 2015). Again, the cognitive idea of creating economic sustainability was central: 'the public finances [being] in equilibrium' is the prime objective, even if this means cutback to popular welfare services (ibid.: 5). This idea was supported by the idea that the public will understand "why cutbacks need to be 
pursued' (ibid.: 7). According to PM Sipilä, cutbacks help to preserve the welfare state, whereas further expansive policies would endanger it and 'send the bill for today's wellbeing to further generations' (YLE, 2015).

This bill also created both consent and opposition in Parliament. MPs from the government parties (CEN, KOK, TF) supported the reform and argued that the restriction is an economic necessity, 'a regrettable saving', but that is not really a question of a cutback, since all children are 'still guaranteed 20 hours of early childhood education and care per week' (Grahn-Laasonen, KOK, PTK 61/2015). Furthermore 'municipalities can still choose to offer full-day childcare' if they want and it they find it necessary from the child's perspective (ibid.) Another argument was that the restriction is supported by the 'majority of the public' (Puumala, CEN, PTK $61 / 2015)$ and that the restriction will be compensated 'by other government investments' (Grahn-Laasonen, KOK, PTK 61/2015), although no specific investment was mentioned. The opposition MPs largely opposed the reform, by suggesting, for instance, that it undermines 'the quality of ECEC services' (Anderson, LEFT, PTK 61/2015), increases social inequality and stigmatization among children 'by dividing them into groups depending on the labour market position of the parents' (Arhinmäki, LEFT, PTK 61/2015), and it is a poor investment, as 'every 1 euro spent on quality childcare gives 7 euro back to the society' (Uotila, LEFT, PTK 61/2015). Furthermore, some opposition MPs argued that parents working part-time not being taken enough into consideration (Östman, CHDEM, PTK 61/2015), and that the restriction is ideologically motivated as a conservative attack on public welfare services (Rinne, SDP, PTK 61/2016). Other MP's supported the reform by highlighting the responsibility of parents 'to care for their children at home' (Räsänen, CHDEM, PTK 77/2015).

Whereas the reactions in the parliament were mixed, the interviewed family policy experts all opposed a restriction of the right to public childcare. One expert suggested the reform is infringing upon 'the freedom of choice for families' when it comes to caring for a child at home or letting the child participate in full-time child care, which has been one of the cornerstones in Finnish family policy. It was also highlighted, that the restriction will have a negative impact on the parental employment rate, since unemployed parents will find it more difficult to look for jobs or to accept job offers as their children do not have right to full-time childcare. In this way, the government was said to undermining its own goals, especially regarding 
female employment but also in terms of reducing the gaps between rich and poor families.

Also in editorials of the leading newspaper, Helsingin Sanomat, there was opposition to the restriction of the subjective right to full-time public childcare, suggesting that this will increase inequality among children and create geographical differences, as richer municipalities, such as in the Helsinki area, will stand an economically better chance to offer full-time childcare (HS 26 Nov 2015). It was also highlighted, that he basic goal of the new childcare legislation (for a discussion, see Lundkvist et al 2017), to provide qualitative early education and care, will not be met due to the restriction (HS 1 Feb 2014; HS 31 Aug 2014). Furthermore, the government was criticised for its reluctance to listen to the experts in the field, who predicted that the restriction will have negative consequences on equality, learning and child wellbeing (HS 24 Jun 2015) and it was pointed out that priorities of the government have shifted since the last recession in the 1990s. Back then, the government was very keen on making public childcare available for all children under seven, regardless of the employment situation of the parents, in order to promote wellbeing, equality, and economic growth. Today this is no longer the case, as politicians seem willing to sacrifice full-day childcare for the sake of financial sustainability (HS, 2 Apr 2014).

\section{Conclusions and discussion}

This article examined the discourse used by Finnish governments for legitimating unpopular reforms in family policy since 2011, namely cutbacks in the child benefit and in public childcare. The aim was to describe the arguments and ideas used in this 'communicative' discourse (Schmidt, 2002) to determine whether this discourse contained elements linked to a neoliberal austerity worldview, and to discuss how 'effective' this austerity discourse was for legitimating the reforms. Based on the findings, a number of conclusions can be drawn.

First, in the discourse on pursuing the reforms the governments mostly used economic, activating, and compensating arguments. The governments were convinced that Finland no longer can afford its (Nordic) universal family policy therefore cutbacks in this policy field is the only alternative, regardless of the consequences, such as increasing child poverty rates and stronger social division. Ideas about social protection being spurring and more activating became evident, 
especially in the case of restricting the subjective right to childcare. By pursuing this reform, the Sipilä government disregarded the important role ECEC plays in creating social equality among children and in minimizing class division (cf. Välimäki, 1999). Not only does this indicate that Finnish family policy is moving towards a more 'hybrid' direction, but it also suggests an ideological turn towards a leaner model of welfare, where work is the primarily source of welfare, welfare services are more conditional, and income transfers become more targeted. Still, this does not necessarily imply an ideological turn to a 'neoliberal' model, since austerity measures can be considered economical necessities in times of acute crisis. To what extent all this actually represents an infringement on the principle of universalism and the Nordic family policy model is still hard to say, but at least the principle of selectivity has become stronger (cf. Ahrendt el al., 2015). Moreover, the government discourse was also influenced by traditional Keynesian and social investment principles, such as social equality, which became visible - for example - in the decision to leave single parents' child benefit supplements uncut.

Second, on basis of the conclusion above, it is clear that the government discourse used for legitimating the cutbacks contained elements from a neoliberal austerity worldview (see table 1). Although austerity measures are not novel in the history of the Finnish welfare state and most European countries employed such measures to recover from the international financial crisis, it is striking how powerful this discourse became in the Finnish case after 2011 and how it trumped everything, including central Nordic family policy principles. The main arguments underpinning the governments' austerity discourse were based on cognitive ideas of economic necessity and there being 'no alternative' to the cutbacks (cf. Schmidt, 2008; Blyth, 2013). Interestingly, the Finnish general government gross debt as percentage of GDP at the time of the cutbacks varied between $48.5 \%$ and $63.6 \%$ (Eurostat, n.d.), which is by no means alarmingly high in international comparison. Still, these 'no alternative' arguments were given precedence, suggesting there were more profound, and ideological, interests at stake. Other cognitive ideas referred to how cost containment actually saves the welfare state and generates financial stability and growth in the long run, and how important it is that we all make 'personal sacrifices', although how this benefits families with children in the long run remains unsaid. Interestingly, the government repeatedly used arguments based on future 
growth and financial sustainability, although the literature on austerity politics (e.g. Blyth, 2013; O'Hara, 2015) agrees that austerity measures do not favour growth.

Third, although we cannot measure the 'effectiveness' in the governments' 'communicative' discourse in creating political and public consent for the reforms, it seems plausible that this discourse was rather effective, especially in the way it created consent within the governments' own ranks. Another way in which it can be seen as effective, is that it managed to frame the discussion about cutbacks in a way that was rather consistent and was based on elements of austerity discourse.

Although the cutbacks were met with hard criticism from not only opposition MPs, family policy experts and partly the media, but also from experts in child welfare from Mannerheim League for Child Welfare [Mannerheimin lastesuojeluliitto] (ÅU 26 Mar 2014; HBL 20 Nov 2015), the government succeeded in carrying them out. Although this need not necessarily be a problem for a united majority coalition in a Finnish parliamentary context with few veto rights, it is still problematic since unpopular reforms can punish the politicians in terms of future electoral losses (Vis, 2010). From a glance at the development of voter support for the three parties in the incumbent government, it seems as if the discourse on cutbacks has been partly successful also from a public point of view. Since pursuing the examined unpopular reforms, the two main parties, the Centre Party and the Conservative Kokoomus, have only suffered minor losses, while the Finns Party have lost about eight percentage points (from $17 \%$ to $9 \%$ ) of its voter support since the general election of 2015 (YLE, 2016).

It seems plausible, then, to conclude that although the economic crisis was the central driver behind the cutbacks made in the Finnish family policies since 2011, the communicative discourse behind the cuts was fuelled by ideas from a neoliberal austerity discourse. In the face of the crisis, the governments chose to cut back on popular welfare programs aiming at protecting families with children. The governments pursued these highly unpopular reforms in spite of objection from other MPs, family policy experts and the media, and even in spite of the political risk it implied. What the long-term effects of these cutbacks will be is still too early hard to say, but they will likely have a negative effect on child poverty and undermine the level of social equality in the Finnish model of welfare.

\section{References}


Anttonen A and Sipilä J (2000) Suomalaista sosiaalipolitiikkaa. Tampere: Vastapaino.

Ahrendt D, Blum S and Crepaldi C (2015) Families in the economic crisis: Changes in policy measures in the EU. Luxembourg: Publications Office of the European Union.

Béland D (2010) The idea of power and the role of ideas. Political Studies Review 8(2): 145-154. DOI: 10.1111/j.1478-9302.2009.00199.x

Béland D and Cox RH (2010) Introduction: Ideas and Politics. In: Béland D and Cox $\mathrm{RH}$ (eds) Ideas and Politics in Social Science Research. New York: Oxford University Press, pp. 1-17.

Blyth M (2013) Austerity: The History of a Dangerous Idea. Oxford: Oxford University Press.

Bradshaw J and Hatland A (2006) Introduction. In: Bradshaw J and Hatland A (eds) Social Policy, Employment and Family Change in Comparative Perspective. Cheltenham: Edward Elgar, pp 1-12.

Clarke J and Newman J (2012) The alchemy of austerity. Critical Social Policy 32(3), 299-319. DOI: $10.1177 / 0261018312444405$

Crouch C (2011) The strange non-death of neoliberalism. Cambridge: Polity Press.

Eurostat (2016) Gender statistics. Available at: http://ec.europa.eu/eurostat/statisticsexplained/index.php/Gender_statistics\#Publications (accessed 1 February 2017)

Eurostat (n.d.) General government gross debt. Avaliable at http://ec.europa.eu/eurostat/tgm/table.do? tab=table\&init $=1 \&$ language $=$ en\&pcode $=$ tsdde410\&plugin $=1$. (Accessed on 1 February 2017).

Farnsworth K and Irving Z (2015). Austerity: more than the sum of its parts. In: Farnsworth K and Irving Z (eds) Social Policy in Times of Austerity. Bristol: The Policy Press, pp. 9-21.

Fischer F (2003) Reframing public policy. Discursive politics and deliberative practices. Oxford: Oxford University Press.

Forssén K, Jaakola A-M and Ritakallio V-M (2008) Family Policies in Finland. In: Ostner I and Schmitt C (eds) Family Policies in the Context of Family Change. Wiesbaden: VS Verlag, pp 75-88.

Harvey D (2005) A Brief History of Neoliberalism. Oxford: Oxord University Press.

Hemerijck A (2013) Changing welfare states. Oxford: Oxford University Press. 
Hiilamo H (2002) The Rise and Fall of Nordic Family Policy? Historical development and changes during the 1990s in Sweden and Finland. PhD Thesis: Turun Yliopisto. Helsinki: Stakes.

Hsieh HF and Shannon S (2005) Three Approaches to Qualitative Content Analysis. Qualitative Health Research, 15(9): 1277-1288. DOI: 10.1177/1049732305276687.

Hufvudstadstbladet [HBL] (2015) "Regeringen vidgar klyftorna mellan barnfamiljer". Available at http://gamla.hbl.fi/nyheter/2015-11-19/779089/regeringen-vidgar-klyftormellan-barnfamiljer

Jorgensen MW and Phillips LJ (2002) Discourse Analysis as Theory and Method. London: Sage.

Korpi W (2000) Faces of Inequality. Gender, Class, and Patterns of Inequalities in Different Types of Welfare States. Social Politics 7(2): 127-191. DOI:

10.1093/sp/7.2.127.

Lammi-Taskula J and Salmi M (2013) Interview in 'Ajantasan lauantaivieras', 5 October, 2013. Available at: http://areena.yle.fi/1-2051013. Accessed 20 January, 2014.

Lammi-Taskula J and Takala P (2009) Finland: negotiating tripartite compromises. In: Kamerman S and Moss $\mathrm{P}$ (eds) The politics of parental leave policies Bristol: Policy Press, pp. 87-102.

Lundkvist M, Nyby J, Autto J and Nygård M (2017) From universalism to selectivity? The background, discourses and ideas of early childhood education and care reforms in Finland. Early child development and care. DOI: 10.1080/03004430.2017.1235041

McBride S (2015) The economics of austerity. In Farnsworth K and Irving Z (eds) Social Policy in times of austerity. Bristol: The Policy Press, pp. 67-85.

Ministry of Finance (2012) Valtiontalouden kehykset vuosille 2013-2016 [State economy framework 2013-2016]. Helsinki: Ministry of Finance. Available at: http://vm.fi/documents/10623/307577/Valtiontalouden+kehykset+vuosille+20132016/677fc144-05df-491e-8e60-78540e14bb80 (accessed 14 Dec 2016)

Nygård M and Autto J (2014) Finnish family policy at the crossroads? The financial crisis and its repercussions on state support for families with children. The 2014 Annual Conference of the Comparative European Politics Specialist Group of the Political Studies Association, UK, A Europe in Crisis, A Europe in Flux, University of Gothenburg, Sweden, November 6-7, 2014.

O'Hara M (2014) Austerity bites. A journey to the sharp end of cuts in the UK. Bristol: Policy Press.

Pohjanpalo O (2015) Eduskunnassa myrskyisä keskustelu: Lapselle jää oikeus 20 tunnin päivähoitoon, Helsingin Sanomat 10 November 15. 
Reuters (2015) Finland, the New 'Sick Man of Europe,' Agonizes Over Austerity. Nov 22, 15. NBC News. Available at: http://www.nbcnews.com/business/economy/finlandnew-sick-man-europe-agonizes-over-austerity-n461761. (Accessed 13 Dec 2016).

Rothbauer P (2008) Triangulation. In: Given L (ed) The SAGE Encyclopaedia of Qualitative Research Methods. London: Sage Publications, pp. 892-894.

Schmidt V (2002) Does Discourse matter in the politics of welfare state adjustment? Comparative Political Studies, 35(2): 168-193. DOI: 10.1177/0010414002035002002

Schmidt V (2008) Discursive Institutionalism: The Explanatory Power of Ideas and Discourse. Annual Review of Political Science 2008(11): 303-326. DOI: 10.1177/0010414002035002002

Stuckler D and Basu S (2013) The Body Economic. Why austerity kills. New York: Basic Books.

Taylor G (2007) Ideology and Welfare. London: Sage.

Wennemo I (1994) Sharing the Costs of Children. Studies on the Development of Family Support in the OECD Countries. PhD Thesis, Stockholm: Sweden.

Vis B (2010) The Politics of Risk-taking. Welfare state reform in advanced democracies. Amsterdam: Amsterdam University Press.

Välimäki A-L (1999) Lasten hoitopuu: Lasten päivähoitojärjestelmä Suomessa 1800ja 1900-luvulla Helsinki: Suomen kuntaliitto.

YLE (2015) Speech by PM Juha Sipilä 16.9.2015. Available at http://yle.fi/uutiset/katso ja lue sipilan_puhe tasta kokonaisuudessaan/8311098 (accessed 13 December 2016).

YLE (2016) Gröna har rekordstöd i Yles mätning - stora partierna närmar sig varandra. Yle Nyheter 8.6.2016. Avaliable at:

http://svenska.yle.fi/artikel/2016/06/08/grona-har-rekordstod-i-yles-matning-storapartierna-narmar-sig-varandra (accessed 13 December 2016).

Åbo Underrättelser [ÅU] (2014) Barnskyddsförbund besviket på nedskärningar i barnunderstöd. Available at http://www.abounderrattelser.fi/news/2014/03/barnskyddsforbund-besviket-panedskarningar-i-barnunderstod.html 
Table 1. Different worldviews on social (and family) policy (a modification of table 1.1. in Morel et al. 2012: 12-3)

\begin{tabular}{|l|l|l|l|}
\hline & $\begin{array}{l}\text { Keynesian } \\
\text { worldview }\end{array}$ & $\begin{array}{l}\text { Social investment } \\
\text { worldview }\end{array}$ & $\begin{array}{l}\text { Neoliberal austerity } \\
\text { worldview }\end{array}$ \\
\hline $\begin{array}{l}\text { Key values } \\
\text { and } \\
\text { principles }\end{array}$ & $\begin{array}{l}\text { Equality of outcome, } \\
\text { full standardised } \\
\text { employment (for } \\
\text { men), } \\
\text { decommodification }\end{array}$ & $\begin{array}{l}\text { Equality of } \\
\text { opportunity, } \\
\text { individual } \\
\text { responsibility, Social } \\
\text { inclusion, creation of } \\
\text { quality jobs, } \\
\text { capabilities approach }\end{array}$ & $\begin{array}{l}\text { Equality of } \\
\text { opportunity, individual } \\
\text { responsibility, freedom } \\
\text { of choice, competition, } \\
\text { creation of any job at } \\
\text { all }\end{array}$ \\
\hline $\begin{array}{l}\text { General } \\
\text { ideas (key } \\
\text { norms for } \\
\text { public } \\
\text { action) }\end{array}$ & $\begin{array}{l}\text { Big state, central } \\
\text { economic planning, } \\
\text { extensive welfare } \\
\text { state }\end{array}$ & $\begin{array}{l}\text { Empowering state, } \\
\text { investments in } \\
\text { human capital, } \\
\text { modernisation of the } \\
\text { welfare state }\end{array}$ & $\begin{array}{l}\text { Limited state } \\
\text { intervention, self- } \\
\text { regulating markets, } \\
\text { deregulation, cutbacks } \\
\text { in social transfers and } \\
\text { benefits, tax cuts, } \\
\text { budget constraint }\end{array}$ \\
\hline $\begin{array}{l}\text { Key policy } \\
\text { ideas }\end{array}$ & $\begin{array}{l}\text { Policies to support } \\
\text { demand, income } \\
\text { redistribution, } \\
\text { development of } \\
\text { social insurance } \\
\text { schemes (income } \\
\text { maintenance) and } \\
\text { public service sectors } \\
\text { (e.g. day care } \\
\text { services), social } \\
\text { protection }\end{array}$ & $\begin{array}{l}\text { Human capital } \\
\text { investments to } \\
\text { increase } \\
\text { competitiveness and } \\
\text { create jobs, } \\
\text { supporting labour } \\
\text { market participation } \\
\text { (of women) through } \\
\text { early childhood } \\
\text { education and day } \\
\text { care services, } \\
\text { education and life- } \\
\text { long learning, active } \\
\text { labour market } \\
\text { policies, flexicurity, } \\
\text { targeted benefits }\end{array}$ & $\begin{array}{l}\text { Monetarist economic } \\
\text { policies to fight } \\
\text { inflation, deregulation } \\
\text { of the labour market, } \\
\text { targeted benefits to } \\
\text { the poor, government } \\
\text { debt reduction, } \\
\text { privatisation of social } \\
\text { and health services, } \\
\text { workfare policies, } \\
\text { fiscal balance, } \\
\text { increase in the } \\
\text { individual's own } \\
\text { responsibility, freedom } \\
\text { of choice }\end{array}$ \\
\hline
\end{tabular}



Table 2 Instructions for coding the neoliberal austerity discourse for research question 2.

\begin{tabular}{|c|c|c|}
\hline $\begin{array}{l}\text { Key policy ideas } \\
\text { (neoliberal } \\
\text { austerity) }\end{array}$ & Description & Example (cognitive and normative idea) \\
\hline Fiscal balance & $\begin{array}{l}\text { Utterances for general } \\
\text { greed for austerity } \\
\text { measures, e.g. to } \\
\text { balance and increase the } \\
\text { public economy }\end{array}$ & $\begin{array}{l}\text { Cognitive idea: limiting public spending safeguards economic growth. } \\
\text { 'Only a secure public economy...can guarantee a sustainable welfare' } \\
\text { 'Wormative idea: social protection needs to be activating. }\end{array}$ \\
\hline $\begin{array}{l}\text { Cost } \\
\text { containment }\end{array}$ & $\begin{array}{l}\text { Utterances for cost } \\
\text { containment, e.g. cutting } \\
\text { the child benefit and } \\
\text { restricting the subjective } \\
\text { right to public child care } \\
\text { in order to reduce public } \\
\text { expenditure }\end{array}$ & $\begin{array}{l}\text { Cognitive idea: austerity measures are a necessity and promote } \\
\text { economic growth in the long run, austerity needed due to weakened } \\
\text { competitiveness due to economic globalization. } \\
\text { 'By index-freezing the child benefit... } \\
\text { benefeduces the cost relating to the child } 2013 \text { by } 38 \text { million Euros' } \\
\text { Normative idea: welfare services are somewhat more connected to } \\
\text { employment situation (accentuation of selectivity alongside } \\
\text { universalism), which also will spur parents to work } \\
\text { 'The idea is to support the provider to [return to or enter] the labour } \\
\text { market..' }\end{array}$ \\
\hline $\begin{array}{l}\text { Targeting of } \\
\text { benefit for those } \\
\text { in need }\end{array}$ & $\begin{array}{l}\text { Utterances for } \\
\text { compensating poor } \\
\text { people or targeting those } \\
\text { in need, e.g. by raising } \\
\text { the sole provider addition } \\
\text { and income support }\end{array}$ & $\begin{array}{l}\text { Cognitive idea: austerity measures a necessity but the most poor still } \\
\text { need protection. } \\
\text { 'By making other benefits [for the poorest] index-linked bond...the } \\
\text { poorest will maintain the purchasing power' } \\
\text { Normative idea: although cutting benefits will increase the rate in child } \\
\text { poverty, the government consider this equally unfair and the best of two } \\
\text { bad options. } \\
\text { 'This cut...is also, from a child's broader perspective, the most } \\
\text { sustainable option [when it comes to cutting the child benefit].' }\end{array}$ \\
\hline $\begin{array}{l}\text { Increase in } \\
\text { individual } \\
\text { responsibility }\end{array}$ & $\begin{array}{l}\text { Utterances relating to } \\
\text { increasing the } \\
\text { individual's responsibility, } \\
\text { e.g. by restricting the } \\
\text { right to public childcare }\end{array}$ & $\begin{array}{l}\text { Cognitive idea: economic sustainability, social expenditure to be scaled } \\
\text { down in relation to economic resources, cost efficiency. } \\
\text { Normative idea: social security need to be activating and spurring, } \\
\text { accentuation of liberty, own responsibility and less [state] regulation, the } \\
\text { state is to have a limited role, welfare services connected to } \\
\text { employment. } \\
\text { 'People have freedom and responsibility to build their own, their } \\
\text { family's...lives.' }\end{array}$ \\
\hline $\begin{array}{l}\text { Freedom of } \\
\text { choice }\end{array}$ & $\begin{array}{l}\text { Utterances relating to } \\
\text { freedom of choice, e.g. } \\
\text { when it comes to } \\
\text { activating social security } \\
\text { (in which child benefit is } \\
\text { included) }\end{array}$ & $\begin{array}{l}\text { Cognitive idea: higher flexibility for parents. } \\
\text { 'Possibilities for families with young children in combining work-life } \\
\text { balance is supported [by the government].' } \\
\text { Normative idea: accentuation on the responsibility of and freedom of } \\
\text { choice of the individual, the state has a (limited) supportive role } \\
\text { 'Support is provided to all people of all ages, to enable them to take } \\
\text { responsibility for their own state of health and lifestyles.' }\end{array}$ \\
\hline $\begin{array}{l}\text { Privatization of } \\
\text { welfare services }\end{array}$ & $\begin{array}{l}\text { Utterances for privatizing } \\
\text { welfare services, e.g. by } \\
\text { raising financial support } \\
\text { for parents who choose } \\
\text { private childcare }\end{array}$ & $\begin{array}{l}\text { Cognitive idea: public expenditure is too expensive. } \\
\text { '...even in normal economic times...the public finances are not } \\
\text { enough...' } \\
\text { Normative idea: more financial support for those choosing private } \\
\text { childcare. } \\
\text { 'A bigger amount will be paid [for those choosing private childcare]...' }\end{array}$ \\
\hline
\end{tabular}


Endnotes 
i Three governments were analysed. The Katainen right-left coalition (2011-2014) included Conservatives, Christian Democrats, Social Democrats, the Left-wing Alliance, the Green League and the Swedish People's party (the Greens and Left-wing alliance left the government in 2013 and 2014, respectively). The Stubb right-left coalition (June 2014May 2015) was an ideological successor of the previous four-party coalition. The Sipilä centre-right coalition (inaugurated May 2015) included the Centre Party, Conservatives and the Finns party.

ii The data consisted of three government programs (2011, 2014 and 2015) with one supplement (2015), two supporting statements (2011 and 2016), four government bills (HE 116/2012 vp, HE 165/2014 vp, HE 70/2015 vp and HE 80/2015 vp), 58 leaders from Helsingin Sanomat (Dec 2011 - Apr 2016). Furthermore, five expert interviews were conducted with leading family policy experts from the Ministry of Social Welfare and Health, Finnish National Social Insurance Institution (KELA) and the National Institute for Health and Welfare (THL).

iii Helsingin Sanomat is the largest daily newspaper in Finland and plays an important role as an independent political commentator and opinion builder. Since 1932 it has been politically independent and party non-aligned.

iv It should be acknowledged, though, that we cannot in fact 'measure' this effect and that any plausible association between discourse and reform is destined to be tentative at best.

v The four cutbacks analysed are the 2012 amendment of the child benefit indexation system (HE 116/2012 vp), the 2014 cutback in child benefits by $8.1 \%$ (HE 165/2014 vp), the 2015 abolishment of child benefit indexation (HE $70 / 2015 \mathrm{vp}$ ) and the 2015 restriction of childcare rights for children with at least one parent at home (HE 80/2015 vp).

vi It should be noted though that local municipalities are responsible for producing childcare services and for collecting user fees.

vii The electoral consequences of the cutbacks are difficult to assess. Some parties, such as the Left-wing alliance left the Katainen right-left coalition in 2014 in protest against the cutbacks and managed to avoid some of the blame in that way. In the case of the Finns Party, however, the restriction of childcare and other cutbacks can explain some of the electoral backlash of the party, from a voter support of approx. $17 \%$ in the 2015 national election to approx. $9 \%$ in June 2016 (YLE, 2016). 